\title{
An experimental and modelling approach for improving utilization rate of the cold roll forming production line
}

\author{
Jurkovic, M. ${ }^{a}$, Jurkovic, Z. ${ }^{a,}{ }^{*}$, Buljan, S. ${ }^{b}$, Obad, M. ${ }^{c}$ \\ ${ }^{\mathrm{a}}$ Faculty of Engineering, University of Rijeka, Rijeka, Croatia \\ ${ }^{\mathrm{b}}$ Federal Ministry of Energy, Mining and Industry, Mostar, Bosnia and Herzegovina \\ ${ }^{c}$ Faculty of Mechanical Engineering, Computing and Electrical Engineering, University of Mostar, Mostar, Bosnia and Herze- \\ govina
}

\begin{abstract}
A B S T R A C T
This paper presents theoretical approach and complex experimental research which was conducted within the real production conditions of cold roll forming channel sections. The experimental investigation was focused on forming forces measuring on the rolls and the deflections of roll stands due to the forming loads. The comparison and analysis of the obtained experimental results was performed for the majority roll stands. Based on the experimental results mathematical modelling of the forming a force-roll load was performed by response surface methodology for different values of the input parameters of the process: material properties, sheet thickness, and sheet width. The defined force model and experimental research show insufficient energetic and technological utilization of the existing production line. After the conducted research in the production process a sheet thickness of up to $1.40 \mathrm{~mm}$ is used instead of $0.70 \mathrm{~mm}$, and the utilization of the installed energy has increased from $20 \%$ to $75 \%$. This is confirmed by the measured deformations of the roll stands and the energy consumption of the powered electric motor. Through realized modernization of the cold roll forming production line, $30 \%$ higher productivity is achieved, which is a result of optimal number planning of roll forming stations and approximately the same load of all roll stands, as well as the higher flow rate of the profile sheet.
\end{abstract}

\section{ARTICLE INFO}

Keywords:

Cold roll forming;

Modelling;

Experimental investigation;

Response surface methodology;

Force-roll load;

Roll stand deflection

*Corresponding author:

zoran.jurkovic@riteh.hr

(Jurkovic, Z.)

Article history:

Received 14 December 2017

Revised 29 January 2018

Accepted 7 February 2018

\section{References}

[1] Scheipers, P. (2002). Handbuch der Metallbearbeitung, Verlag Europa-Lehrmittel, Haan-Gruiten, Germany.

[2] Halmos, G.T. (2006). Roll forming handbook, CRC Press, Boca Raton, USA.

[3] Brandegger, R. (2004). Predicting stress and strain in roll formed profiles, The Fabricator, Vol. 34, No. 5, 56-57.

[4] Lange, K. (1994). Handbook of metal forming, SME, Dearborn, USA.

[5] Schuler GmbH (1998). Metal forming handbook, Springer-Verlag, Berlin Heidelberg, Germany, doi: 10.1007/9783-642-58857-0.

[6] Kuzman, K. (2001). Problems of accuracy control in cold forming, Journal of Materials Processing Technology, Vol. 113, No. 1-3, 10-15, doi: 10.1016/S0924-0136(01)00688-4.

[7] Bhattacharyya, D., Smith, P.D., Thadakamalla, S.K., Collins, I.F. (1987). The prediction of roll load in cold rollforming, Journal of Mechanical Working Technology, Vol.14, No.3,363-379, doi:10.1016/0378-3804(87)90019-2.

[8] Paralikas, J., Salonitis, K., Chryssolouris, G. (2010). Optimization of the roll forming process parameters - a semiempirical approach, The International Journal of Advanced Manufacturing Technology, Vol. 47, No. 9-12, 10411052, doi: 10.1007/s00170-009-2252-z.

[9] Paralikas, J., Salonitis, K., Chryssolouris, G. (2009). Investigation of the effects of main roll-forming process parameters on quality for a V-section profile from AHSS, The International Journal of Advanced Manufacturing Technology, Vol. 44, No. 3-4, 223-237, doi: 10.1007/s00170-008-1822-9. 
[10] Traub, T., Chen, X., Groche, P. (2017). Experimental and numerical investigation of the bending zone in roll forming, International Journal of Mechanical Sciences, Vol. 131-132, 956-970, doi: 10.1016/j.ijmecsci.2017.07.056.

[11] Viet, B.Q., Papeleux, L., Boman, R., Ponthot, J.-P., Wouters, P., Kergen, R., Daolio, G. (2005). Numerical simulation of cold roll forming process, In: Proceedings of the 8th ESAFORM Conference on material forming, Cluj-Napoca, Romania, 141-144.

[12] Lindgren, M. (2007). Cold roll forming of a U-channel made of high strength steel, Journal of Materials Processing Technology, Vol. 186, No. 1-3, 77-81, doi: 10.1016/i.jmatprotec.2006.12.017.

[13] Lindgren, M. (2005). Modelling and simulation of the roll forming process, Licentiate thesis, Luleå University of Technology, Sweden.

[14] Paralikas, J., Salonitis, K., Chryssolouris, G. (2013). Energy efficiency of cold roll forming process, The International Journal of Advanced Manufacturing Technology, Vol. 66, No. 9-12, 1271-1284, doi: 10.1007/s00170-0124405-8.

[15] Ferreira, P.B.F. (2016). Roll forming - A study on machine deflection by means of experimental analysis and numerical developments, Master of science thesis, Faculty of Engineering, University of Porto, Portugal.

[16] Jurkovic, M., Jurkovic, Z., Obad, M., Buljan, S., Mustafic, E. (2015). An investigation of the force and torque at profile sheet metal rolling - Input data for the production system reengineering, Tehnički Vjesnik - Technical Gazette, Vol. 22, No. 4, 1029-1034, doi: 10.17559/TV-20150310092726.

[17] Zeng, G., Li, S.H., Yu, Z.Q., Lai, X.M. (2009). Optimization design of roll profiles for cold roll forming based on response surface method, Materials \& Design, Vol. 30, No. 6, 1930-1938, doi: 10.1016/i.matdes.2008.09.018.

[18] Liu, C.-F., Zhou, W.-L., Fu, X.-S., Chen, G.-Q. (2015). A new mathematical model for determining the longitudinal strain in cold roll forming process, The International Journal of Advanced Manufacturing Technology, Vol. 79, No. 5-8, 1055-1061, doi: 10.1007/s00170-015-6845-4.

[19] Wang, H., Yan, Y., Jia, F., Han, F. (2016). Investigations of fracture on DP980 steel sheet in roll forming process, Journal of Manufacturing Processes, Vol. 22, 177-184, doi: 10.1016/j.jmapro.2016.03.008.

[20] Hasanagić, N. (2013). Theoretical and experimental research of the force of sheet metal profiling by rollers, (original title: Teoretsko i eksperimentalno istraživanje sile profilisanja lima pomoću valjaka), Master of science thesis, Bihać, Bosnia and Herzegovina.

[21] Jušić, A. (2013). Theoretical research and experimental diagnostics load production line for the forming of open profile of the sheet metal by rollers, (original title: Teorijsko istraživanje i eksperimentalna dijagnostika opterećenja proizvodne linije za oblikovanje otvorenih profila iz lima pomoću valjaka), Master of science thesis, Bihać, Bosnia and Herzegovina.

[22] Jurković, M., Jušić, A., Hasanagić, N. (2013). Experimental diagnostics line profiling sheet metal using rollers, In: Proceedings of the 9th International Scientific Conference on Production Engineering, Budva, Montenegro, 69-74.

[23] Jurković, M. (1999). Mathematical modelling and optimization of machining processes, (original title: Matematičko modeliranje i optimizacija obradnih procesa), Faculty of Engineering University of Rijeka, Rijeka, Croatia. 